Фролов В. С., канд. військ. наук., ст. наук. співроб. (0000-0003-0105-6439)

Центр воєнно-стратегічних досліджень Національного університету оборони України імені Івана Черняховського, Київ

\title{
Обгрунтування науково-методичних підходів до розроблення організаційної структури Збройних Сил України за стандартами НАТО
}

Резюме. У статті проведено аналіз існуючого наукового підходу до розроблення проєкту структури Збройних Сил України з урахуванням принципів і стандартів НАТО. Зважаючи на результати аналізу пропонується методичний підхід до розроблення проєкту структури ЗС України із застосуванням методу аналізу ієрархій Т. Сааті.

Ключові слова: військове будівництво; збройні сили; боєздатність збройних сил; оперативностратегічне угруповання військ (сил).

Постановка проблеми. Конституцією та законами України визначено основний вектор розвитку зовнішньополітичного курсу держави - інтеграція у євроатлантичну систему колективної безпеки.

Керівництво НАТО та Міністерство оборони України на саміті у листопаді 2019 року погодили новий підхід до надання допомоги Україні за принципом "одна країна - одна програма". Зміст іiї полягає в об'єднані усіх існуючих програм допомоги Україні у єдину програму. Так, наприклад, на сьогодні допомога Україні здійснюється за окремими програмами: Building integrity, Defense education enhancement program, професійного розвитку, "Наука заради миру і безпеки", взаємодія 3 агенцією НАТО 3 питань підтримки i постачання, взаємодія 3 командувачем об'єднаними силами НАТО в Європі, взаємодія із Силами спецоперацій, стратегічних авіаперевезень тощо.

Суть нового, узгодженого формата полягає у тому, що усі окремі програми та інші види діяльності об'єднуються у єдину програму співробітництва "Україна-НАТО", яка базуватиметься на "Комплексному пакеті допомоги", діючому з 2016 року, та матиме єдиний секретаріат у Брюсселі та Києві. Пріоритети надання допомоги визначатимуться Україною.

Безумовно, що основу взаємної сумісності армій держав-членів НАТО, насамперед, складає організаційна структура їх збройних сил, на якій базуються системи військового управління та всебічного забезпечення.

Звідси, також, практичний інтерес щодо удосконалення організаційної структури Збройних Сил України відповідно до нових умов інтеграційних процесів вступу України в НАТО викликає нагальну потребу застосування наукових підходів до коригування існуючої організаційної структури ЗС України.

Аналіз низки проведених досліджень i практичної діяльності керівництва МО та ЗС України показує, що Генеральним штабом протягом останніх років широко і активно розробляються варіанти новітніх систем управління військами та всебічного забезпечення ЗС України, засоби і способи автоматизації функціонування органів управління, здійснюється освоєння важливих стандартів, прийнятих в арміях державчленів НАТО. Так, Міністерством оборони і Генеральним штабом Збройних Сил України розроблений та затверджений Президентом України Стратегічний оборонний бюлетень, Міністр оборони затвердив План дій щодо впровадження оборонної реформи (Дорожня карта), у яких сплановані заходи, повне виконання яких забезпечить підготовку України до вступу в НАТО.

Отже, стає можливим констатувати, що у Міністерстві оборони та Збройних Силах України розгорнута та організована цілеспрямована планова робота щодо широкомасштабного реформування армії на основі досягнень сучасної воєнної науки та досвіду провідних країн світу. Водночас, варто зазначити, що в процесі цього значного обсягу роботи уточненню організаційної структури Збройних Сил України, яка на сьогодні не зовсім співпадає з вимогами теорії воєнного мистецтва та 3 організаційними структурами армій держав-членів НАТО, уваги, на жаль, приділяється недостатньо, завдяки чому глибина обгрунтування деяких змін часто не така як слід.

Метою статті $\mathbf{\epsilon}$ наукове обгрунтування методичних підходів до визначення організаційної структури Збройних Сил 
України, яка б відповідала, з одного боку основним принципам і стандартам НАТО, 3 іншого - вимогам сучасного воєнного мистецтва за досвідом ведення воєнних дій в Україні.

Виклад основного матеріалу. Військове будівництво - це частина воєнної справи, що включає в себе теорію і практику створення (формування, реформування) збройних сил (сил оборони) держави, відповідно до прогнозуємих умов розвитку глобальної, $\quad$ регіональної та внутрішньодержавної воєнно-політичної обстановки, 3 опорою на взаємозв'язані економічні, соціально-політичні, військові та інші заходи щодо створення та удосконалення системи оборони держави.

Уперше термін “збройні сили” застосував Фрідріх Енгельс для об'єднання визначень "сухопутні війська" та "військовоморський флот", а з 1858 року термін використовувався і в Російській імперії. Для ведення воєнних дій у відповідній сфері - на суші, на морі, у повітряному та космічному просторі - збройні сили поділяються на види збройних сил, кожному із яких притаманні свої, специфічні завдання, а, відповідно, і свої, специфічні, часто досить вартісні, системи озброєння та військової техніки. Отже, в основі оборонного потенціалу будь-якої держави лежить організаційна структура збройних сил, яка залежить від загроз національним інтересам у військовій сфері, фінансово-економічних можливостей, обсягу мобілізаційних ресурсів держави, членства у воєнно-політичних блоках тощо.

Сучасна теорія воєнного мистецтва передбачає чіткий розподіл збройних сил на організаційні структури мирного часу та угруповання військ (сил), що формуються для підготовки та ведення воєнних дій. Польовий статут Сухопутних військ армії США FM 3.0 "Операції", визначає, що організаційна структура збройних сил мирного часу формується відповідно до рівнів війни стратегічного, оперативного, тактичного. Для кожного рівня війни формується відповідна організаційна структура збройних сил, на основі якої розробляються системи управління військами та всебічним забезпеченням.

Зважаючи ж на те, що часові рамки загрозливого періоду в сучасних умовах мають надто виражену тенденцію до неухильного скорочення, а Стратегічний план застосування збройних сил, як правило, не співпадає 3 реальними діями агресора, загальна організаційна структура 3С України мирного часу має бути максимально наближеною до структури елементів оперативного шикування угруповань військ (сил) та бойових порядків тактичних з'єднань.

Водночас, система управління військами (силами), відповідно до принципів НАТО, залишається незмінною як у мирний, так і у воєнний час, незалежно від організаційної структури 3С України (рис. 1).

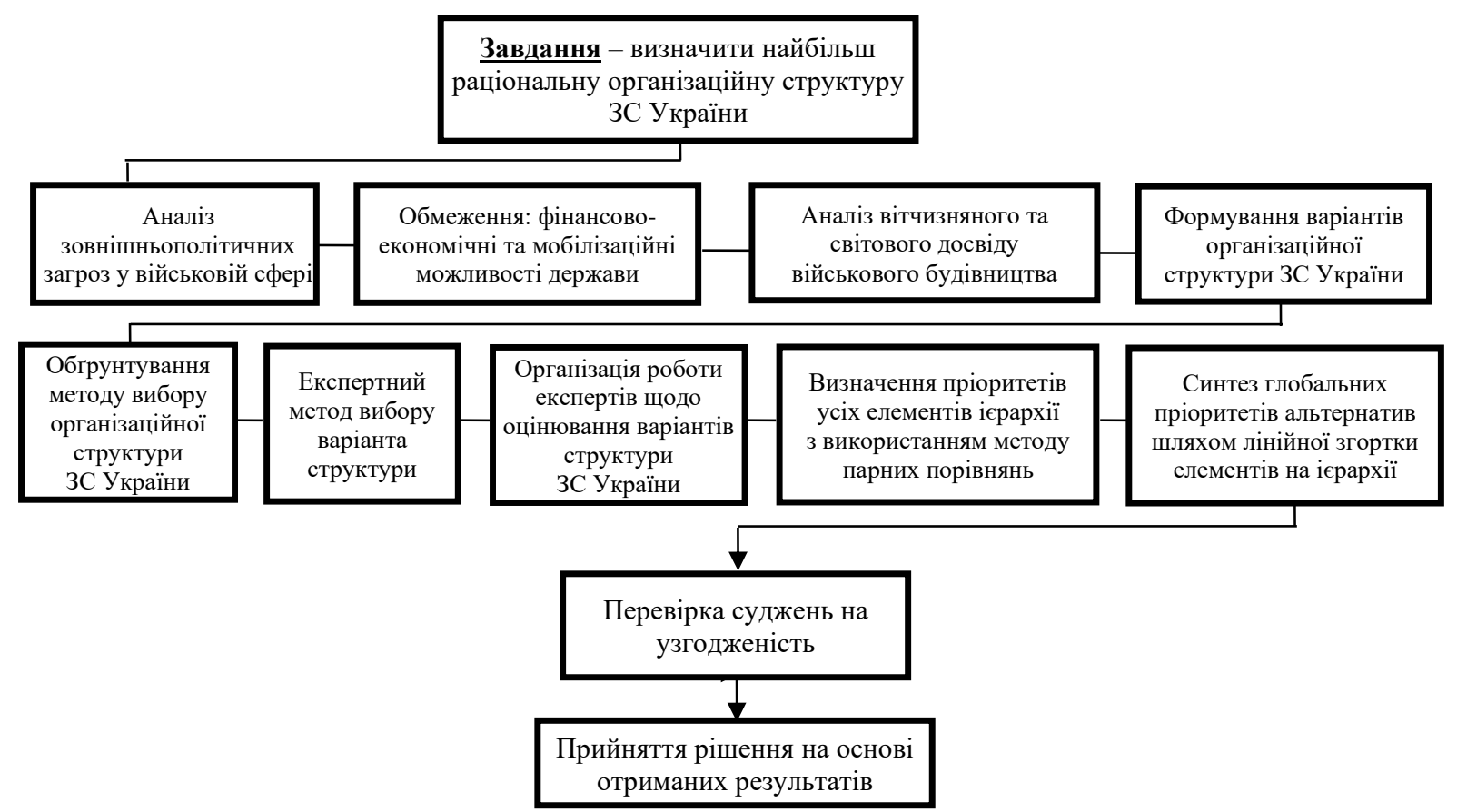

Рис. 1. Структурно-логічна схема визначення організаційної структури ЗС Украйни 
Розв'язання задачі розпочинається 3 аналізу глобальної і регіональної воєннополітичної та воєнно-стратегічної обстановки, визначення очікуваного характеру і масштабу можливих загроз Україні у військовій сфері. Висновки 3 аналізу глобальної і регіональної воєнно-політичної та воєнно-стратегічної обстановки, очікуваний характер і масштаб можливих загроз становлять базу для розрахунку загальної структури та потрібного бойового потенціалу збройних сил. Водночас, структура збройних сил та їх бойовий потенціал обмежуються фінансовоекономічними та мобілізаційними можливостями держави. Обмеження враховуються під час формування проєкту структури збройних сил, розрахунку їх чисельності, оснащення озброєнням, технікою та матеріальними ресурсами. Варіанти організаційної структури Збройних Сил розробляються на підставі вимог сучасної теорії воєнного мистецтва, набутого досвіду ведення бойових дій i рекомендацій Головнокомандувача 3C України i керівництва Генерального штабу.

Одним 3 основних етапів проведення наукового дослідження $\epsilon$ обгрунтування методу вибору організаційної структури збройних сил (рис. 2). У цьому дослідженні застосовується метод аналізу ієрархій (MAI).

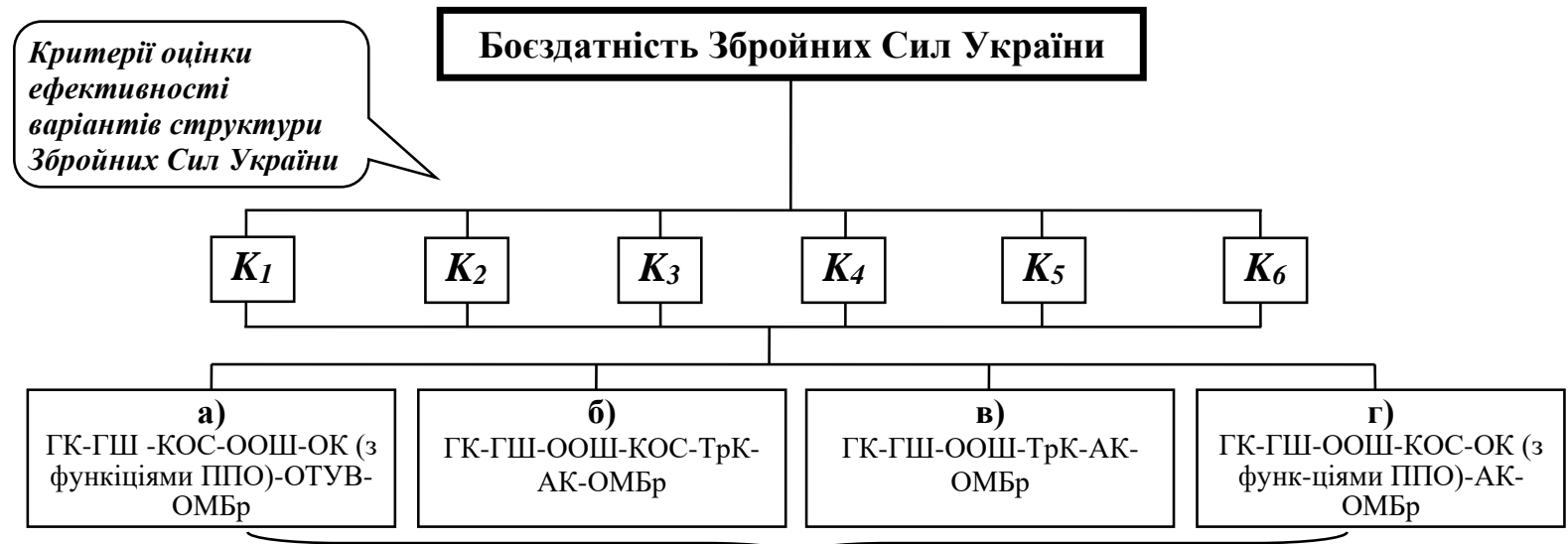

Варіанти структури Збройних Сил України

Рис. 2. Структура визначення варіанта організаційної структури 3С України на основі застосування методу аналізу ієрархій (MAI)

Розглядаючи критерії рівня боєздатності збройних сил, передбачається визначення найбільш раціональної структури, що забезпечує мінімальні строки формування, своєчасного розгортання та приведення у готовність угруповань військ (сил) ЗС України оперативно-стратегічного та оперативнотактичного рівнів для захисту територіальної цілісності держави.

Критерї очінки ефективності варіантів структури Збройних Сил Украӥни:

$\boldsymbol{K}_{\boldsymbol{l}}$ - термін формування і розгортання оперативно-стратегічного та оперативнотактичних угруповань військ (сил) 3С України для відбиття агресії.

$\boldsymbol{K}_{\mathbf{2}}$ - термін розгортання командних пунктів і системи управління військами на оперативно-стратегічному та оперативнотактичному рівнях.

$\boldsymbol{K}_{3}$ - термін розгортання та ефективність функціонування системи матеріальнотехнічного забезпечення угруповань військ (сил) 3С України на оперативно-стратегічному та оперативно-тактичних рівнях.
$\boldsymbol{K}_{\boldsymbol{4}}$-термін і надійність організації взаємодії 3 органами управління інших складових сил оборони та органами місцевого самоврядування у зоні ведення операції оперативно-стратегічним та оперативнотактичним угрупованнями військ (сил) ЗС України.

$\boldsymbol{K}_{5}$ - ефективність

управління територіальною обороною у зоні військового конфлікту та на всій території держави.

$\boldsymbol{K}_{\boldsymbol{6}}-$ надійність управління системою протиповітряної оборони держави. Украйни:

Варіанти структури Збройних Сил

Bapiaнt A: ГК ЗС - ГШ - КОС - ООШ - ОК (з функціями ППО) - ОТУВ - ОМБр.

Головнокомандувач ЗС України та підпорядкований йому Генеральний штаб.

Командувач об'єднаних сил та підпорядкований йому Об'єднаний оперативний штаб.

Оперативне командування із функціями ППО держави.

"Оперативно-тактичне угруповання військ” (ОТУВ). Тимчасово сформоване 
угруповання військ (сил) оперативнотактичного рівня під керівництвом групи генералів та офіцерів від Оперативних командувань Сухопутних військ ЗС України. Утворюється у загрозливий період або під час відбиття агресії противника. Порядок створення та управління ОТУВ на поточний час будь-якими доктринальними документами не визначено.

Військові частини та окремі підрозділи. Бригади, полки та підрозділи тактичного рівня.

Bapiaнт Б: ГК ЗС - ГШ - КОС - ООШ - ТрК - АK - ОМбр.

Головнокомандувач 3С України та підпорядкований йому Генеральний штаб.

Командувач об'єднаних сил та підпорядкований йому Об'єднаний оперативний штаб.

Територіальні

командування.

Командування в складі Сухопутних військ 3С України оперативно-тактичного рівня, призначене для управління зонами територіальної оборони, обліком, підготовкою та подачею мобілізаційних резервів до сил оборони, виконує завдання військового управління в умовах правового режиму воєнного стану.

Армійський корпус. Оперативнотактичне угруповання військ Сухопутних військ бригадного складу. Має постійний штаб, частини та підрозділи всебічного забезпечення. Кількість бригад (окремих полків) може змінюватись залежно від оперативних завдань.

Бригади, військові частини та окремі підрозділи.

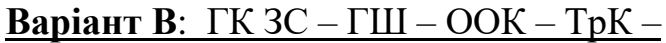
AK- OMбр.

Головнокомандувач 3С України та підпорядкований йому Генеральний штаб.

Об'єднане оперативне командування. Командування та штаб постійного складу, призначені для планування та управління застосуванням оперативно-стратегічного міжвидового (міжвідомчого) угруповання військ (сил) під час підготовки та відбиття агресії. ООК створюється у мирний час iз підпорядкованими органами управління та військовими частинами всебічного забезпечення. 3 переходом на стандарти НАТО створюється система всебічного забезпечення за функціями операцій.

Територіальні командування.

Армійські корпуси.

Бригади, військові частини та окремі підрозділи.
Bapiaнт $\Gamma$ : ГК - ГШ - ООШ - КОС ОК (з функц. ППО) - АК - ОМбр.

Головнокомандувач ЗС України та підпорядкований йому Генеральний штаб.

Об'єднаний оперативний штаб.

Командування об'єднаних сил.

Оперативні командування із функціями ППО держави.

Армійські корпуси.

Бригади, військові частини та окремі підрозділи.

Сутність методу полягає у декомпозиції проблеми на більш прості складові частини і поетапному встановлені пріоритетів оцінюваних компонентів із використанням парних (попарних) порівнянь.

На першому етапі виявляються найважливіші елементи проблеми. На другому - проводяться розрахунки щодо визначення найкращого способу перевірки спостережень, випробування та оцінювання елементів. На третьому - обгрунтовується спосіб застосування рішення i оцінювання його якості.

Одним із важливих елементів організації застосування MAI $є$ етап підбору та організації роботи експертної групи. Від компетентності експертів залежить достовірність і об'єктивність наукового дослідження.

Зміст наступних чотирьох етапів дослідження полягає у визначенні пріоритетів усіх елементів ієрархії із використанням методу парних порівнянь, синтезу глобальних пріоритетів альтернатив 3 використанням лінійної згортки елементів на ієрархії та перевірки суджень на узгодженість. Заключним етапом $є$ прийняття рішення на основі отриманих результатів наукового дослідження.

Перший рівень MAI - декомпозиція та представлення задачі в ієрархічній формі, що включає мету дослідження, яка полягає у досягненні максимального рівня боєздатності Збройних Сил України.

Другий рівень - критерії, від яких залежить вибір варіантів третього рівня MAI.

Третій рівень - варіанти організаційної структури 3С України.

Для успішної реалізації методу, введено закон ієрархічної безперервності, відповідно до якого елементи кожного рівня мають порівнюватись відносно елементів вищого рівня. Між рівнями будуються матриці: одна матриця для порівняння відносно важливості критеріїв стосовно мети дослідження та матриці для оцінювання відносної значущості 
альтернатив щодо кожного 3 критеріїв другого рівня.

Число матриць між рівнем критеріїв i альтернатив дорівнює числу критеріїв.

Метод Т. Сааті для оцінювання компонент рекомендує спеціальну шкалу від 1 до 9, у якій компонентам рівної важливості присвоюється 1, у разі помірної переваги - 3, у разі істотної переваги - 9 (Табл. 1).

Матриці попарних порівнянь усіх рівнів iєрархії проводяться за визначенням їх ступеня важливості, що наведено у Табл. 2.

Таблиця 1

Шкала відносної важливості

\begin{tabular}{|c|c|c|}
\hline $\begin{array}{c}\text { Ступінь } \\
\text { важливості }\end{array}$ & Визначення & Пояснення \\
\hline 1 & Однакова важливість & $\begin{array}{l}\text { Два фактори вносять однаковий вклад у } \\
\text { досягнення мети }\end{array}$ \\
\hline 3 & $\begin{array}{l}\text { Помірне переважання одного фактора } \\
\text { над іншим (слабка значимість) }\end{array}$ & $\begin{array}{l}\text { Досвід і судження дають легку перевагу } \\
\text { одному чиннику над іншим }\end{array}$ \\
\hline 5 & Істотна або сильна значимість & $\begin{array}{l}\text { Досвід і судження дають сильну перевагу } \\
\text { одному чиннику над іншим }\end{array}$ \\
\hline 7 & Дуже сильна або очевидна значимість & $\begin{array}{l}\text { Перевага одного чинника над іншим дуже } \\
\text { сильна }\end{array}$ \\
\hline 9 & Абсолютна значимість & $\begin{array}{l}\text { Свідчення на користь уподобання одного } \\
\text { фактора іншому найвищою мірою переконливі }\end{array}$ \\
\hline $2,4,6,8$ & $\begin{array}{l}\text { Проміжні значення між } \\
\text { значеннями шкали }\end{array}$ & Застосовуються в компромісних випадках \\
\hline
\end{tabular}

Таблиця 2

Середні узгодженості для випадкових матриць

\begin{tabular}{|l|l|l|c|c|c|c|}
\hline $\mathrm{n}$ & 1 & 2 & 3 & 4 & 5 & 6 \\
\hline $\mathrm{BI}$ & 0 & 0 & 0,58 & 0,9 & 1,12 & 1,24 \\
\hline
\end{tabular}

3 теорії матриць відомо, що погодженість зворотно симетричної матриці (яка $є$ результатом застосування експертом методу парних порівнянь за шкалою Т. Сааті) еквівалентна вимогам рівності ㄲi максимального власного значення $\lambda_{\max }$ i числа порівнюваних об'єктів $\mathrm{n}\left(\lambda_{\max }=\mathrm{n}\right)$.

Отже, як міру неузгодженості, розглянемо нормоване відхилення $\lambda_{\max }$ від $n$, яке називають індексом погодженості - IП:

$$
I \Pi=\frac{\lambda_{\max }-n}{n-1} \text {. (1) }
$$

Для того щоб оцінити, чи є отримане узгодження прийнятним чи нi, його порівнюють 3 випадковим індексом - $B I$.

$$
B \Pi=I \Pi / B I \cdot
$$

Випадковим індексом (BI) називають індекс погодженості, розрахований для квадратної $n$-мірної позитивної зворотно симетричної матриці, елементи якої генеровані датчиком випадкових чисел (табл. 2). Розрахунки міри неузгодженості розглянемо для кожної матриці, які заповнюються експертами.

У матриці попарних порівнянь важливості критеріїв оцінки варіантів структури 3С України (Табл. 3) визначається ієрархія важливості (вектори пріоритетів) кожного критерію щодо їх впливу на рівень боєздатності ЗС України. Кожен експерт розраховує свій варіант матриці.

Таблиця 3

Матриця попарних порівнянь важливості критеріїв оцінки варіантів структур

3бройних Сил України для визначення їх впливу на боєздатність

\begin{tabular}{|c|c|c|c|c|c|c|c|c|}
\hline Критерії & $\boldsymbol{K}_{\boldsymbol{1}}$ & $\boldsymbol{K}_{\mathbf{2}}$ & $\boldsymbol{K}_{\mathbf{3}}$ & $\boldsymbol{K}_{\boldsymbol{4}}$ & $\boldsymbol{K}_{\boldsymbol{5}}$ & $\boldsymbol{K}_{\boldsymbol{6}}$ & $\begin{array}{l}\sqrt[6]{ } \\
(* \text { Kn })\end{array}$ & $\begin{array}{c}\text { Вектор } \\
\text { пріоритетів }\end{array}$ \\
\hline $\boldsymbol{K}_{\boldsymbol{1}}$ & 1 & $3 / 5(0.6)$ & $2 / 3(0.7)$ & $7 / 3(2.3)$ & $5 / 4(1.25)$ & $5 / 2(2.5)$ & 1.2 & $\mathbf{0 . 1 9}$ \\
\hline $\boldsymbol{K}_{\boldsymbol{2}}$ & $5 / 3(1.7)$ & 1 & $5 / 3(1.7)$ & $7 / 3(2.3)$ & $7 / 4(1.75)$ & $7 / 5(1.4)$ & 1.59 & $\mathbf{0 . 2 5}$ \\
\hline $\boldsymbol{K}_{\boldsymbol{3}}$ & $3 / 2(1.5)$ & $3 / 5(0.6)$ & 1 & $7 / 4(1.75)$ & $7 / 4(1.75)$ & $3 / 5(0.6)$ & 1.01 & $\mathbf{0 . 1 6}$ \\
\hline $\boldsymbol{K}_{\boldsymbol{4}}$ & $3 / 7(0.43)$ & $3 / 7(0.43)$ & $4 / 7(0.57)$ & 1 & $5 / 2(2.5)$ & $2 / 7(0.29)$ & 0.65 & $\mathbf{0 . 1 1}$ \\
\hline $\boldsymbol{K}_{\boldsymbol{5}}$ & $4 / 5(0.8)$ & $4 / 7(0.57)$ & $4 / 7(0.57)$ & $2 / 5(0.4)$ & 1 & $3 / 5(0.6)$ & 0.63 & $\mathbf{0 . 1}$ \\
\hline $\boldsymbol{K}_{\boldsymbol{6}}$ & $2 / 5(0.4)$ & $5 / 7(0.7)$ & $5 / 3(1.7)$ & $7 / 2(3.5)$ & $5 / 3(1.7)$ & 1 & 1.19 & $\mathbf{0 . 1 9}$ \\
\hline Всього & 5.8 & 3.9 & 6.2 & 11.2 & 9.9 & 6.4 & 6.3 & \\
\hline
\end{tabular}


$\lambda \max =(5.8 \times 0.19)+(3.9 \times 0.25)+(6.2 \times 0.16)+(11.2 \times 0.11)+(9.9 \times 0.1)+(6.4 \times 0.19)=$

$=1.1+0.97+0.99+1.2+0.99+1.2=\underline{\mathbf{6 . 4 2}} ; \boldsymbol{I I}=(6.42-6) /(6-1)=0.42 / 5=\underline{\mathbf{0 . 0 8}} ; \boldsymbol{B} \boldsymbol{\Pi}=0.08 / 1.24=\underline{\mathbf{0 . 0 6}}$

Отже, розрахунки, які проведені одним 3 попарних порівнянь кожного 3 4-х варіантів експертів у табл. 3, показують, що критерій строків готовності системи управління військами $\boldsymbol{K}_{2} \in$ найважливішим із шести критеріїв оцінки боєздатності ЗС України і складає 0.25 .

Наступним кроком дослідження $\epsilon$ проведення розрахунків у шести матрицях організаційної структури ЗС України для кожного $з$ шести критеріїв.

У Табл. 4 наведено приклад розрахунків попарних порівнянь варіантів організаційної структури ЗС України для критерію $\boldsymbol{K}_{\boldsymbol{l}}$, проведених одним з одинадцяти експертів.

Таблиця 4

Матриця попарних порівнянь свосчасності розгортання оперативно-стратегічного та оперативно-тактичного угруповань військ (сил) (Критерій 1)

\begin{tabular}{|c|c|c|c|c|c|c|}
\hline $\begin{array}{c}\text { Варіанти } \\
\text { структури } \\
\text { ЗС України }\end{array}$ & $\mathbf{A}$ & $\mathbf{6}$ & $\mathbf{B}$ & $\boldsymbol{\Gamma}$ & & $\begin{array}{c}\text { Вектор } \\
\text { пріоритетів }\end{array}$ \\
\hline $\mathbf{A}$ & 1 & $2 / 5(0.4)$ & $4 / 7(0.57)$ & $2 / 3(0.67)$ & 0.62 & $\mathbf{0 . 1 5}$ \\
\hline $\mathbf{6}$ & $5 / 2(2.5)$ & 1 & $4 / 5(0.8)$ & $5 / 3(1.7)$ & 1.09 & $\mathbf{0 . 2 6}$ \\
\hline $\mathbf{B}$ & $7 / 4(1.75)$ & $5 / 4(1.25)$ & 1 & $7 / 3(2.3)$ & 1.5 & $\mathbf{0 . 3 8}$ \\
\hline $\boldsymbol{\Gamma}$ & $3 / 2(1.5)$ & $3 / 5(0.6)$ & $3 / 7(0.43)$ & 1 & 0.79 & $\mathbf{0 . 2 1}$ \\
\hline & 6.7 & 3.25 & 2.8 & 5.7 & 4 & \\
\hline
\end{tabular}

$\lambda \max =(6.7 \times 0.15)+(3.25 \times 0.26)+(2.8 \times 0.38)+(5.7 \times 0.21)=\mathbf{1}+\mathbf{0 . 9}+\mathbf{1 . 0 6}+\mathbf{1 . 2}=\mathbf{4 . 1 6}$

$I \Pi=(4.16-4) /(4-1)=0.16 / 3=\underline{\mathbf{0 . 0 5}} ; \quad B \Pi=0.05 / 0.9=\underline{\mathbf{0 . 0 5}}$

Подібні матриці розробляються та заповнюються одинадцятьма експертами для кожного $з$ шести критеріїв.

Обчислення вектора пріоритетів 3 урахуванням варіантів думок експертів здійснюється методом розрахунку середньо геометричного значення за формулою:

$$
a_{i j}=\sqrt[n]{\prod_{k-1}^{n} a_{i j}^{(k)}},
$$

Обчислення векторів пріоритетів кожного критерію оцінки організаційної структури ЗС України щодо впливу на боєздатність збройних сил, показане на матриці розрахунків векторів пріоритетів 3 урахуванням думок усіх експертів (Табл. 5). Розрахунки здійснюються 3 урахуванням думок експертів, визначених ними у заповнених матрицях попарних порівнянь важливостей критеріїв оцінки варіантів організаційної структури 3С Україна (Табл. 3).

де $a_{i j}$ - компонента вектора пріоритету

визначена $\mathrm{k}-м$ експертом; $n$ - кількість експертів.

Таблиця 5

Матриця розрахунків пріоритетів критеріїв з урахуванням думок експертів

\begin{tabular}{|c|c|c|c|c|c|c|c|c|c|c|c|c|}
\hline $\begin{array}{c}\text { Важливість } \\
\text { критріїв }\end{array}$ & $E_{1}$ & $E_{2}$ & $E_{3}$ & $E_{4}$ & $E_{5}$ & $E_{6}$ & $E_{7}$ & $E_{8}$ & $E_{9}$ & $E_{10}$ & $E_{11}$ & $K_{\Pi i}$ \\
\hline $\boldsymbol{K}_{1}$ & 0.19 & 0.19 & 0.19 & 0.15 & 0.18 & 0.19 & 0.28 & 0.21 & 0.2 & 0.18 & 0.19 & 0.19 \\
\hline $\boldsymbol{K}_{2}$ & 0.25 & 0.26 & 0.24 & 0.22 & 0.28 & 0.18 & 0.26 & 0.29 & 0.27 & 0.28 & 0.24 & 0.25 \\
\hline $\boldsymbol{K}_{3}$ & 0.16 & 0.17 & 0.17 & 0.21 & 0.18 & 0.19 & 0.21 & 0.15 & 0.16 & 0.17 & 0.17 & 0.17 \\
\hline $\boldsymbol{K}_{4}$ & 0.11 & 0.09 & 0.09 & 0.08 & 0.07 & 0.09 & 0.08 & 0.07 & 0.1 & 0.08 & 0.09 & 0.1 \\
\hline $\boldsymbol{K}_{5}$ & 0.1 & 0.1 & 0.14 & 0.16 & 0.13 & 0.15 & 0.14 & 0.11 & 0.09 & 0.14 & 0.14 & 0.13 \\
\hline $\boldsymbol{K}_{6}$ & 0.19 & 0.19 & 0.17 & 0.18 & 0.16 & 0.2 & 0.03 & 0.17 & 0.18 & 0.17 & 0.17 & 0.16 \\
\hline
\end{tabular}

Примітка. Таблиця 5 - обчислення важливості кожного критерію на боєздатність ЗС України на думку експертів.

$$
\begin{aligned}
& K_{\Pi 1}=\sqrt[11]{\prod_{\mathrm{i}=1}^{11} K_{1}\left(E_{i}\right)}=0,19 ; K_{\Pi 2}=\sqrt[11]{\prod_{\mathrm{i}=1}^{11} K_{2}\left(E_{i}\right)}=0,25 ; \quad K_{\Pi 3}=\sqrt[11]{\prod_{\mathrm{i}=1}^{11} K_{3}\left(E_{i}\right)}=0,17 \\
& K_{\Pi 14}=\sqrt[11]{\prod_{\mathrm{i}=1}^{11} K_{4}\left(E_{i}\right)}=0,1 ; \quad K_{\Pi 5}=\sqrt[11]{\prod_{\mathrm{i}=1}^{11} K_{5}\left(E_{i}\right)}=0,13 ; \quad K_{\Pi 6}=\sqrt[11]{\prod_{\mathrm{i}=1}^{11} K_{6}\left(E_{i}\right)}=0,16 .
\end{aligned}
$$

Отже, за підсумками проведених обчислень (Табл. 5), отримали пріоритетність критеріїв оцінки боєздатності ЗС України відповідно до думок, які висловили усі одинадцять експертів.

За їхніми висновками найбільш важливим критерієм, який впливає на 
боєздатність ЗС України $\epsilon$ критерій $K_{2}-$ термін розгортання командних пунктів i системи управління військами на оперативностратегічному та оперативно-тактичному рівнях $\left(K_{2}=0.25\right)$.

У Табл. 6 показано зразок однієї з 4-x матриць розрахунку пріоритетів кожного варіанта організаційної структури Збройних Сил України за оцінкою одного експерта. Кожна 3 4-х матриць відповідає запропонованим варіантам (A, Б, В, Г) організаційної структури ЗС України.

Таблиця 6

Матриця розрахунків пріоритетів першого варіанта організаційної структури ЗС України (варіант А)

\begin{tabular}{|l|l|l|l|l|l|l|l|l|l|l|l|c|}
\hline $\begin{array}{l}\text { Варіант } A \\
\text { стуктури } \\
\text { 3С України }\end{array}$ & $E_{1}$ & $E_{2}$ & $E_{3}$ & $E_{4}$ & $E_{5}$ & $E_{6}$ & $E_{7}$ & $E_{8}$ & $E_{9}$ & $E_{10}$ & $E_{11}$ & $\begin{array}{c}\text { Пріоритети } \\
\text { струкури } \boldsymbol{A} \\
A_{\Sigma}\left(K_{i}\right)\end{array}$ \\
\hline$A_{K_{1}}$ & 0.15 & 0.17 & 0.1 & 0.13 & 0.14 & 0.12 & 0.16 & 0.15 & 0.12 & 0.13 & 0.16 & $\mathbf{0 . 1 5}$ \\
\hline$A_{K_{2}}$ & 0.17 & 0.15 & 0.3 & 0.22 & 0.2 & 0.21 & 0.22 & 0.24 & 0.3 & 0.28 & 0.25 & $\mathbf{0 . 1 6}$ \\
\hline$A_{K_{3}}$ & 0.19 & 0.22 & 0.18 & 0.16 & 0.17 & 0.18 & 0.17 & 0.16 & 0.16 & 0.18 & 0.17 & $\mathbf{0 . 1 8}$ \\
\hline$A_{K_{4}}$ & 0.18 & 0.15 & 0.13 & 0.18 & 0.15 & 0.16 & 0.14 & 0.13 & 0.14 & 0.12 & 0.14 & $\mathbf{0 . 1 7}$ \\
\hline$A_{K_{5}}$ & 0.15 & 0.16 & 0.15 & 0.16 & 0.18 & 0.19 & 0.16 & 0.18 & 0.15 & 0.14 & 0.13 & $\mathbf{0 . 1 6}$ \\
\hline$A_{K_{6}}$ & 0.16 & 0.15 & 0.14 & 0.15 & 0.16 & 0.14 & 0.15 & 0.14 & 0.13 & 0.15 & 0.15 & $\mathbf{0 . 1 8}$ \\
\hline
\end{tabular}

Примітка. Таблиця 6 - обчислення кожним експертом важливості варіантів структури ЗС України відповідно до кожного критерію оцінки боєздатності 3С України - всього 4х1 1=44 таблиці.

$$
\begin{aligned}
& A_{\Sigma}\left(K_{1}\right)=\sqrt[11]{\prod_{\mathrm{i}=1}^{11} A_{K_{1}}\left(E_{i}\right)}=0,15 ; A_{\Sigma}\left(K_{2}\right)=\sqrt[11]{\prod_{\mathrm{i}=1}^{11} A_{K_{2}}\left(E_{i}\right)}=0,16 \quad A_{\Sigma}\left(K_{3}\right)=\sqrt[11]{\prod_{\mathrm{i}=1}^{11} A_{K_{3}}\left(E_{i}\right)}=0,18 ; \\
& A_{\Sigma}\left(K_{4}\right)=\sqrt[11]{\prod_{\mathrm{i}=1}^{11} A_{K_{4}}\left(E_{i}\right)}=0,17 ; A_{\Sigma}\left(K_{5}\right)=\sqrt[11]{\prod_{\mathrm{i}=1}^{11} A_{K_{5}}\left(E_{i}\right)}=0,16 ; A_{\Sigma}\left(K_{6}\right)=\sqrt[11]{\prod_{\mathrm{i}=1}^{11} A_{K_{6}}\left(E_{i}\right)}=0,18 .
\end{aligned}
$$

За такою ж методикою проведено обчислення інших пріоритетів кожного варіанта організаційної структури ЗС України, з урахуванням думок усіх експертів:

$$
\begin{gathered}
S_{\Sigma}\left(K_{1}\right)=0,26 ; D_{\Sigma}\left(K_{2}\right)=0,2 ; S_{\Sigma}\left(K_{3}\right)=0,21 ; B_{\Sigma}\left(K_{4}\right)=0,21 ; S_{\Sigma}\left(K_{5}\right)=0,22 ; b_{\Sigma}\left(K_{6}\right)=0,21 ; \\
B_{\Sigma}\left(K_{1}\right)=0,38 ; B_{\Sigma}\left(K_{2}\right)=0,45 ; B_{\Sigma}\left(K_{3}\right)=0,39 ; B_{\Sigma}\left(K_{4}\right)=0,38 ; B_{\Sigma}\left(K_{5}\right)=0,39 ; B_{\Sigma}\left(K_{6}\right)=0,36 ; \\
\Gamma_{\Sigma}\left(K_{1}\right)=0,21 ; \Gamma_{\Sigma}\left(K_{2}\right)=0,19 ; \Gamma_{\Sigma}\left(K_{3}\right)=0,24 ; \Gamma_{\Sigma}\left(K_{4}\right)=0,24 ; \Gamma_{\Sigma}\left(K_{5}\right)=0,23 ; \Gamma_{\Sigma}\left(K_{6}\right)=0,25 .
\end{gathered}
$$

Методом попарного порівняння векторів пріоритетів визначених критеріїв оцінки впливу на боєздатність ЗС України та пріоритетів організаційної структури ЗС України проводяться розрахунки щодо визначення найбільш ефективного варіанта організаційної структури ЗС України за оцінкою експертів.

У Табл. 7 перший рядок заповнюється обчисленими 3 табл. 5, що відповідають векторам пріоритетів кожного визначеного критерію.
Інші строки матриці (табл. 7) заповнюються результатами обчислень, що проводились у матрицях розрахунків пріоритетів кожного варіанта організаційної структури варіантів організаційної структури ЗС України (А, Б, В, Г) (Табл. 6).

Глобальний вектор показує найбільш раціональний варіант організаційної структури ЗС України, який, за думкою експертів, забезпечить максимальний рівень боєздатності ЗС України (Табл. 7).

Таблиця 7

Визначення глобальних пріоритетів

\begin{tabular}{|c|c|c|c|c|c|c|c|}
\hline $\begin{array}{c}\text { Варіанти } \\
\text { стуукури } \\
\text { 3С України }\end{array}$ & $\boldsymbol{\kappa}_{\boldsymbol{I}}$ & $\boldsymbol{\kappa}_{\mathbf{2}}$ & $\boldsymbol{\kappa}_{\mathbf{3}}$ & $\boldsymbol{\kappa}_{\boldsymbol{4}}$ & $\boldsymbol{\kappa}_{5}$ & $\boldsymbol{\kappa}_{\boldsymbol{6}}$ & $\begin{array}{c}\text { Глобальні } \\
\text { пріоритети }\end{array}$ \\
\hline$K_{\Pi i}$ & 0.19 & 0.24 & 0.17 & 0.1 & 0.13 & 0.16 & \\
\hline $\boldsymbol{A}$ & 0.15 & 0.16 & 0.18 & 0.17 & 0.16 & 0.18 & $\mathbf{0 . 1 6}$ \\
\hline $\boldsymbol{E}$ & 0.26 & 0.2 & 0.21 & 0.21 & 0.22 & 0.21 & $\mathbf{0 . 2 2}$ \\
\hline $\boldsymbol{B}$ & 0.38 & 0.45 & 0.39 & 0.38 & 0.39 & 0.36 & $\mathbf{0 . 4}$ \\
\hline $\boldsymbol{\Gamma}$ & 0.21 & 0.19 & 0.24 & 0.24 & 0.23 & 0.25 & $\mathbf{0 . 2 2}$ \\
\hline
\end{tabular}


Примітка. Таблиця 7 - обчислення найбільш раціонального варіанта організаційної структури ЗС України.

$$
\begin{aligned}
\Gamma_{\Pi a}= & (0,15 \times 0,19)+(0,16 \times 0,24)+(0,18 \times 0,17)+(0,1 \times 0.17)+(0,13 \times 0,16)+(0.16 \times 0.18)=0.16 ; \\
& \Gamma_{\Pi \sigma}=(0.19 \times 0.26)+(0.24 \times 0.2)+(0.17 \times 0.21)+(0.1 \times 0.21)+(0.13 \times 0.22)+(0.16 \times 0.21)=0.22 ; \\
& \Gamma_{\Pi b}=(0.19 \times 0.38)+(0.24 \times 0.45)+(0.39 \times 0.17)+(0.1 \times 0.38)+(0.13 \times 0.39)+(0.16 \times 0.36)=0.4 ; \\
& \Gamma_{\Pi 2}=(0.19 \times 0.21)+(0.19 \times 0.24)+(0.17 \times 0.24)+(0.1 \times 0.24)+(0.13 \times 0.23)+(0.25 \times 0.16)=0.22 .
\end{aligned}
$$

Отже, на думку експертів, варіант $\boldsymbol{B}$ штабу під час проведення заходів організаційної структури 3 С України має найбільший глобальний вектор $(0,4), \quad \epsilon$ найбільш раціональним та рекомендується керівництву Збройних Сил України для прийняття остаточного рішення щодо організаційної структури Збройних Сил України.

Висновки. Результати дослідження показують:

організаційна структура Збройних Сил України суттєво впливає на їх боєздатність, систему управління військами та організацію всебічного забезпечення;

основними критеріями боєздатності 3С України можуть бути: строки розгортання угруповань військ (сил) оперативностратегічного та оперативно-тактичного рівнів; строки готовності системи управління військами та системи всебічного забезпечення; готовність територіальної оборони держави та надійність системи протиповітряної оборони держави;

найбільш раціональною організаційною структурою ЗС України може бути структура, яка включає: ООК, як постійний орган управління оперативно-стратегічним угрупованням військ (сил); армійські корпуси (або дивізії), як структури оперативнотактичного рівня; територіальні командування, як органи управління системою територіальної оборони; систему протиповітряної оборони держави під єдиним керівництвом Командування Повітряних сил ЗС України;

метод аналізу ієрархій доцільно застосовувати персоналом Генерального реформування Збройних Сил України.

Напрям подальших досліджень полягає розробленні науково-обгрунтованих моделей i програм організаційно-штатної структури видів ЗС України, методик формування оперативно-стратегічних та оперативно-тактичних угруповань військ (сил) 3С України в особливий період, розроблення керівних документів щодо їх підготовки та застосування в особливий період.

\section{СПИСОК ВИКОРИСТАНОЇ ЛІТЕРАТУРИ}

1. Конституція України. Відомості Верховної Ради України (ВВР), 1996. № 30. ст. 141.

2. Про національну безпеку України : Закон України від 21.06.2018 р. № 2489-V111.

3. Про рішення Ради національної безпеки i оборони України від 20 травня 2016 року "Про Стратегічний оборонний бюлетень України" : Указ Президента України від 06.06.2016 р. № 240/2016.

4. План дій оборонної реформи у $2016-2020$ роках (Дорожня карта оборонної реформи) : затв. Міністром оборони України 15.08.2016 p.

5. Сиротенко А. М. Сучасні погляди на форми та способи застосування угруповань військ (сил) Збройних Сил України, інших військових формувань та правоохоронних органів держави під час спільних дій // Спільні дії військових формувань і правоохоронних органів держави: проблеми та перспективи : збірник тез доповідей П'ятої Всеукраїнської науково-практичної конференції. 2018. С. 8-10.

6. Польовий статут Сухопутних військ США. FM 3.0 (“ОПЕРАЦІї”), ГШ ЗС України. Серпень 2016.

7. Саати Т. Принятие решений. Метод анализа иерархий. Москва : Радио и связь, 1993. 278 с.

Стаття надійшла до редакційної колегії 24.02.2020

\section{Substantiation of scientific and methodological approaches to the development of the organizational structure of the Armed Forces of Ukraine by NATO standards}

\section{Annotation}

Following the Constitution and laws of Ukraine, the country has determined the basic vector of further development of the foreign policy of the state - integration into the Euro-Atlantic collective security system.

At present one of the main tasks of the state is to improve the organizational structure of the Armed Forces of Ukraine to the new conditions of integration processes before joining NATO. Adjustment of the existing organizational structure of the Armed Forces will require the application of appropriate scientific approaches.

The purpose of the article is to substantiate methodological approaches to determining the organizational structure of the Armed Forces of Ukraine. This must meet, on the one hand, the basic principles and standards of 
NATO, and on the other hand, the requirements of modern military art, based on an analysis of the experience of warfare in the east.

One of the main stages of scientific research is to justify the method of choosing the organizational structure of the Armed Forces of Ukraine. This study uses the method of Analytic Hierarchy Process (AHP).

The results of the study show:

- the organizational structure of the Armed Forces significantly influences their combat capability, the system of military control and the organization of comprehensive security;

- the main criteria for combat effectiveness of the Armed Forces could be:

1) terms of deployment of troops (forces) of operational-tactical and operational-strategic levels;

2) terms of readiness of the military control system and comprehensive security system;

3) state territorial defense readiness and state air defense system reliability;

- the most rational organizational structure of the Armed Forces may be a structure that includes:

1) joint operational commands as the main governing body of the operational-strategic grouping of troops (forces);

2) army corps (or divisions) as structures of operational and tactical level;

3) territorial commands as bodies managing the territorial defense system;

4) the state's Air Defense System led by the Air Force Command.

Keywords: military building; armed forces; battle-worthiness of the armed forces; operational-strategic groupment of troops (forces). 